\title{
17 $\beta$-Estradiol Delivered in Eye Drops: Evidence of Impact on Protein Networks and Associated Biological Processes in the Rat Retina through Quantitative Proteomics
}

\author{
Laszlo Prokai $^{1,2, *(\mathbb{D}) \text {, Khadiza Zaman }}{ }^{1}\left(\mathbb{D}\right.$, Vien Nguyen ${ }^{1}$ and Katalin Prokai-Tatrai ${ }^{1,2}$ (D) \\ 1 Department of Pharmacology and Neuroscience, University of North Texas Health Science Center, \\ Fort Worth, TX 76107, USA; Khadiza.Zaman@unthsc.edu (K.Z.); Vien.Nguyen@unthsc.edu (V.N.); \\ Katalin.Prokai@unthsc.edu (K.P.-T.) \\ 2 Institute for Healthy Aging, University of North Texas Health Science Center, Fort Worth, TX 76107, USA \\ * Correspondence: Laszlo.Prokai@unthsc.edu; Tel.: +1-817-735-2206
}

Received: 19 December 2019; Accepted: 22 January 2020; Published: 27 January 2020

\begin{abstract}
To facilitate the development of broad-spectrum retina neuroprotectants that can be delivered through topical dosage forms, this proteomics study focused on analyzing target engagements through the identification of functional protein networks impacted after delivery of $17 \beta$-estradiol in eye drops. Specifically, the retinae of ovariectomized Brown Norway rats treated with daily eye drops of $17 \beta$-estradiol for three weeks were compared to those of vehicle-treated ovariectomized control animals. We searched the acquired raw data against a composite protein sequence database by using Mascot, as well as employed label-free quantification to detect changes in protein abundances. Our investigation using rigorous validation criteria revealed 331 estrogen-regulated proteins in the rat retina (158 were up-regulated, while 173 were down-regulated by $17 \beta$-estradiol delivered in eye drops). Comprehensive pathway analyses indicate that these proteins are relevant overall to nervous system development and function, tissue development, organ development, as well as visual system development and function. We also present 18 protein networks with associated canonical pathways showing the effects of treatments for the detailed analyses of target engagements regarding potential application of estrogens as topically delivered broad-spectrum retina neuroprotectants. Profound impact on crystallins is discussed as one of the plausible neuroprotective mechanisms.
\end{abstract}

Keywords: eye drops; estradiol; female rats; retina; proteomics; label-free quantitation; pathway analysis; biological networks; target engagement; crystallin

\section{Introduction}

The development of clinical interventions targeting eye diseases with new chemical entities has been burdened by increasing costs and high rate of regulatory failures [1]. Therefore, medical needs unmet by currently marketed ocular drug products have been emerging [2]. For example, preventative, disease-modifying, or adjuvant medications that would thwart or remedy damage to retinal neurons by a group of complex and slow-progressing neurodegenerative eye diseases such as glaucoma, diabetic retinopathy, or age-related macular degeneration have remained elusive [3]. However, it has been recognized that many approved drugs can be repurposed for ocular pharmacotherapy $[4,5]$, or utilized as direct lead compounds to develop ophthalmic pharmaceuticals [6-8]. Another challenge is that pathology-associated neuronal damage in the retina exhibits multiple mechanisms of yet to be understood complexity, which calls for polypharmacology (which recognizes the necessity for a single drug to exert effects on multiple targets and disease pathways) as a preventative and/or therapeutic 
approach [9]. In addition, eye drops have remained the most common route of ophthalmic drug delivery despite their noted limitations [10,11]. Altogether, preferred therapeutic candidates for the purpose would be broad-spectrum retina neuroprotectants [12] that could be delivered even using simple topical applications [10].

The pleiotropic and tissue-specific action of estrogens has been the subject of many important basic and translational studies [13]. Besides their well-researched reproductive function [14], they also impact the central nervous system (CNS) by multiple genomic and non-genomic mechanisms that are often implicated in preventative and therapeutic contexts $[15,16]$. These include broad-spectrum neuroprotection against the aging of the retina and age-related ocular neurodegenerative diseases $[17,18]$. In fact, estrogen deficiency has been linked recently to a glaucoma phenotype in mice [19]. Our previous studies have convincingly shown that administration of $17 \beta$-estradiol $\left(\mathrm{E}_{2}\right)$ as eye drops can provide therapeutic drug levels in the retina, which was associated with profound protection of retinal ganglion cells and preservation of visual acuity in a rat glaucoma model [20]. However, understanding how the hormone acts in the retina has remained rudimentary, and few estrogen-regulated retinal proteins have been identified to date [21], even relying on early proteomics studies [20,22]. Here, we present an expanded study relying on our previous in vivo experimental design [20], but performed using a newer, more powerful instrument for label-free quantitative proteomic analyses. In particular, we reveal potential therapeutic target engagements through the identification of functional protein networks for future translational studies focused on retina neuroprotection after $E_{2}$ delivery in eye drops.

\section{Materials and Methods}

\subsection{Chemicals and Reagents}

$\mathrm{E}_{2}$, 2-hydroxypropyl- $\beta$-cyclodextrin, urea, dithiothreitol, iodoacetamide, ammonium bicarbonate, and formic acid (ACS reagent grade, $\geq 98 \%$ ) were purchased from MilliporeSigma (St. Louis, MO, USA). Sequencing-grade trypsin was obtained from Promega (Madison, WI, USA). Water and acetonitrile were Optima ${ }^{\circledR}$ LC/MS grade, and supplied by Thermo Fisher Scientific (Waltham, MA, USA).

\subsection{Animals and Treatments}

All procedures involving animals were reviewed and approved by the Institutional Animal Care and Use Committee at the University of North Texas Health Science Center before the initiation of the studies (approval number: 2018-0028, on 10 July 2018). Five ovariectomized (OVX) Brown Norway rats (Charles Rivers Laboratories, Wilmington, DE, USA) weighing 200-250 g received $10 \mu \mathrm{L}$ of $17 \beta$-estradiol $\left(E_{2}\right)$ eye drops once daily in both eyes for three weeks [20]. The eye drops contained $0.1 \%$ $(w / v) \mathrm{E}_{2}$ in saline vehicle containing $20 \%(w / v)$ 2-hydroxypropyl- $\beta$-cyclodextrin. Five OVX control rats received $10 \mu \mathrm{L}$ of this vehicle as eye drops for the same dosing regimen and duration. After $24 \mathrm{~h}$ of the last treatment, they were euthanized, and their eyes were immediately enucleated followed by rapid isolation of the retina. Tissue samples were rinsed with saline and then blotted dry for preparation to label-free shotgun proteomic analyses according to previously published methods [20,23].

\subsection{Sample Preparation}

Each isolated retina was prepared first by incubating in $200 \mu \mathrm{L} 8 \mathrm{M}$ aqueous urea solution for $30 \mathrm{~min}$ followed by centrifugation for $5 \mathrm{~min}$ at $1400 \times g$ [20,23]. The supernatant was collected, and protein content was measured using a microplate reader (BioTek Synergy H1 with Take3 plate; Agilent, Santa Clara, CA, USA). An aliquot containing $100 \mu \mathrm{g}$ protein was taken and the volume was adjusted with $25 \mathrm{mM}$ ammonium bicarbonate to $100 \mu \mathrm{L}$. The sample was then reduced with dithiothreitol and carbamidomethylated with iodoacetic amide [20,23]. After 9-fold dilution of the sample with aqueous $25 \mathrm{mM}$ ammonium bicarbonate, trypsin digestion was performed at $37^{\circ} \mathrm{C}$ overnight, then the reaction was quenched by acidification with formic acid $(1 \mu \mathrm{L})$. The solution was desalted by solid-phase extraction (SPE) using $1 \mathrm{~mL}$ Sep-Pak ${ }^{\mathrm{TM}}$ C18 SPE cartridges (Waters, Milford, 
MA, USA), and the extract was dried under vacuum (Vacufuge ${ }^{\mathrm{TM}}$, Eppendorf AG, Hamburg, Germany) into a $1.5 \mathrm{~mL}$ centrifuge tube.

\subsection{Proteomics Analyses}

The digested samples were analyzed using a hybrid ion trap-Orbitrap tandem mass spectrometer (LTQ Velos Orbitrap Pro) coupled to an EASY nLC-1000 nanoflow liquid chromatography system fitted with a $15 \mathrm{~cm} \times 75 \mu \mathrm{m}$ i.d. EasySpray column packed with $3 \mu \mathrm{m}$ PepMap C18 particles (Thermo Fisher Scientific, San Jose, CA, USA). Gradient elution was used: Solvent A and solvent B were water and acetonitrile, respectively, and each contained $0.1 \%(v / v)$ formic acid. Samples (100 $\mu$ g protein) were reconstituted in $100 \mu \mathrm{L}$ of solvent containing $5 \%(v / v)$ acetonitrile and $0.1 \%(v / v)$ formic acid in water and transferred into $200 \mu \mathrm{L}$ polypropylene autosampler vials closed with an open-top screw cap and Teflon-lined silicon septum (USA Scientific, Orlando, FL, USA). During a 20 min column equilibration at $5 \% \mathrm{~B}, 5 \mu \mathrm{L}$ of solution was injected while maintaining constant column pressure at 600 bar. The peptides were eluted at $300 \mathrm{~nL} / \mathrm{min}$ using the following gradient: (1) $5 \mathrm{~min}$ isocratic at $5 \% \mathrm{~B}$; (2) linear program to $40 \%$ B over $90 \mathrm{~min}$ and then (3) isocratic at $40 \%$ B for $5 \mathrm{~min}$; (4) to $90 \% \mathrm{~B}$ over $5 \mathrm{~min}$; (6) isocratic at $90 \% \mathrm{~B}$ for $5 \mathrm{~min}$; and (6) resetting to $5 \% \mathrm{~B}$ in $20 \mathrm{~min}$. The mass spectrometer was operated in positive-ion nanoelectrospray (nanoESI) mode with source voltage of $2.0 \mathrm{kV}$ and ion-transfer tube temperature of $275^{\circ} \mathrm{C}$. Full-scan mass spectra (MS) were acquired at 60,000 resolution in the Orbitrap and up to 20 MS-dependent tandem mass spectra (MS/MS) were obtained in the ion trap for each full spectrum acquired using collision-induced dissociation (CID) of multiply-charged ions $(z \geq 2)$. Dynamic exclusion was set for $60 \mathrm{~s}$ after an ion was selected for fragmentation. Two technical replicates were run for each sample.

\subsection{Data Processing and Statistical Analysis}

MS/MS spectra were searched against the UniProt protein sequence database (species: Rattus norvegicus, 29938 entries) using the Mascot search engine (version 2.6.2; Matrix Science, Boston, MA, USA) run from Proteome Discoverer (version 2.3; Thermo Fisher Scientific). A parent ion mass tolerance and fragment ion mass tolerance were set to $25 \mathrm{ppm}$ and 0.80 Da respectively, and we allowed only one missed cleavage in our search filters. Cysteine carbamidomethylation was indicated as fixed modification and methionine oxidation was designated as variable modification. We used Scaffold software (version 4.9.0, Proteome Software Inc.; Portland, OR, USA) to validate our search results using the Peptide Prophet [24] and Protein Prophet [25] algorithms requiring over 95\% and 99\% probabilities, respectively, and at least two identified unique peptides for each protein. We have also deposited our data to the ProteomeXchange Consortium [26] by the PRIDE partner repository (assigned dataset identifier: PXD010851). Our label-free quantification relied on spectral counting [23] built into the Scaffold software, and $p<0.05$ was considered significantly different using unpaired $t$-tests for statistical comparison between sample categories. We also considered twofold change in spectral counts as a threshold of biological effect. Missing values, if any, were handled using Scaffold's default method and settings. The identified $E_{2}$-regulated proteins were submitted to Ingenuity Pathway Analysis ${ }^{\circledR}$ (IPA ${ }^{\circledR}$, QIAGEN, Redwood City, CA, USA; https://www.qiagenbioinformatics.com/products/ingenuitypathway-analysis/) to derive bioinformatics annotations along with potential protein interaction networks, as well as associated biological functions and processes. Overlaps of $p$-values were reported from IPA ${ }^{\circledR}$ 's calculations using the right-tailed Fisher's exact test [27].

\section{Results}

From the collected raw data files, protein database search by Mascot within Proteome Discoverer and validation by Scaffold's algorithms resulted in 1680 actual protein identifications (in 1236 clusters) with $0.01 \%$ and $0.4 \%$ false discovery at the peptide and protein levels, respectively, according to a decoy-based method of estimation (Table S1). Biological processes and molecular processes associated with the identified rat retina proteins, as well as their cellular localization were summarized in Figure S1. 
Of the 1680 proteins identified using stringent criteria described in Section 2.5 and using spectral counting as the method of label-free quantification, 158 were up-regulated, while 173 proteins were down-regulated by $\mathrm{E}_{2}$ in the retina of OVX rats (Table S2).

Top molecular and cellular functions, as well as physiological development and function influenced by $E_{2}$ based on bioinformatics analyses $\left(\operatorname{IPA}^{\circledR}\right)$ were summarized in Table 1 . Two representatives of the 18 protein interaction networks assembled using $E_{2}$-regulated retinal proteins as inputs for $\mathrm{IPA}^{\circledR}$ are displayed in Figures 1 and 2, and selected canonical pathways and targets associated with these networks are listed in Tables 2 and 3, respectively. Details on the rest of the networks are included in the supplementary material (Figures S2-S18). Networks shown in Figure 2 called our attention to crystallins as potential major players orchestrating the hormone's action strongly related to development disorder, ophthalmic disease, as well as organismal injury and abnormalities. Indeed, we found that all covered isoforms of these proteins were upregulated in the retina upon topical $\mathrm{E}_{2}$ treatments, as shown in Figure 3.

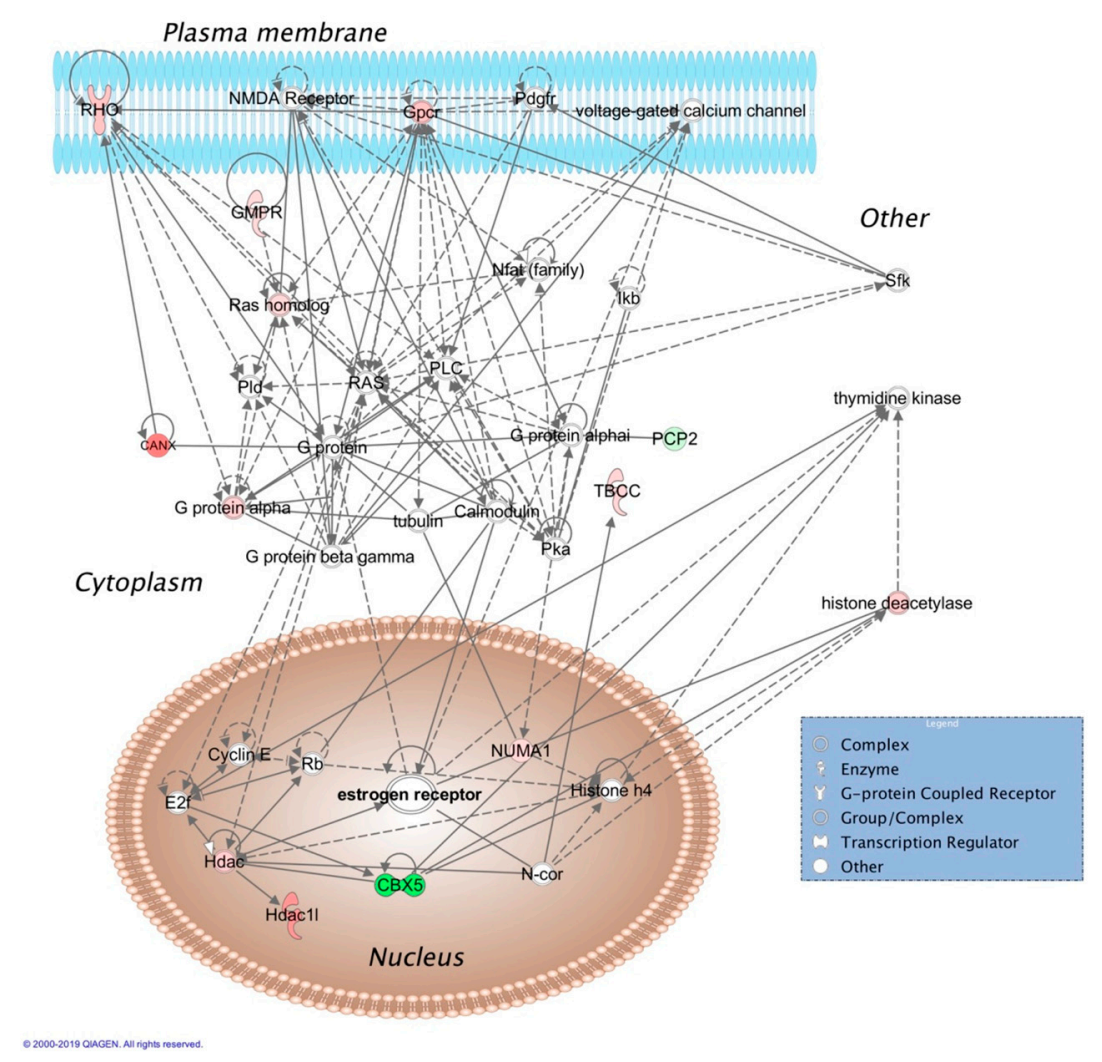

Figure 1. Cell morphology, cell to cell signaling, cellular growth, function, and morphology-related molecular interaction network assembled from retina proteins impacted by topical $\mathrm{E}_{2}$ to OVX Brown Norway rats. The shapes (see legend in blue box) represent molecular classes of the regulated proteins. In the network, red and green colors denote upregulation and downregulation in response to E2 treatment, respectively. The intensity of color indicates the relative magnitude of fold change in protein expression pattern. Solid and dashed lines represent direct and indirect interactions, respectively. Abbreviations: CANX, calnexin; CBX5, chromobox 5; E2f, E2F transcription regulator; ERK, extracellular signal-regulated kinase; Gpcr, G-protein coupled receptor; GMPR, guanosine monophosphate reductase; Hdac, histone deacetylase; Ikb, Iк-B; MAPK, mitogen-activated protein kinase; N-cor, nuclear receptor corepressor; Nfat, nuclear factor of activated T-cells; NMDA, N-methyl-D-aspartic acid; NUMA1, nuclear mitotic apparatus 1; PCP2, Purkinje cell protein 2; Pdgfr, platelet-derived growth factor receptor; Pka, protein kinase A; PLC, phospholipase C; Pld, phospholipase D; Rb, Rb tumor suppressor; RHO, rhodopsin; Sfk, Src family kinase; TBCC, tubulin folding cofactor C. 


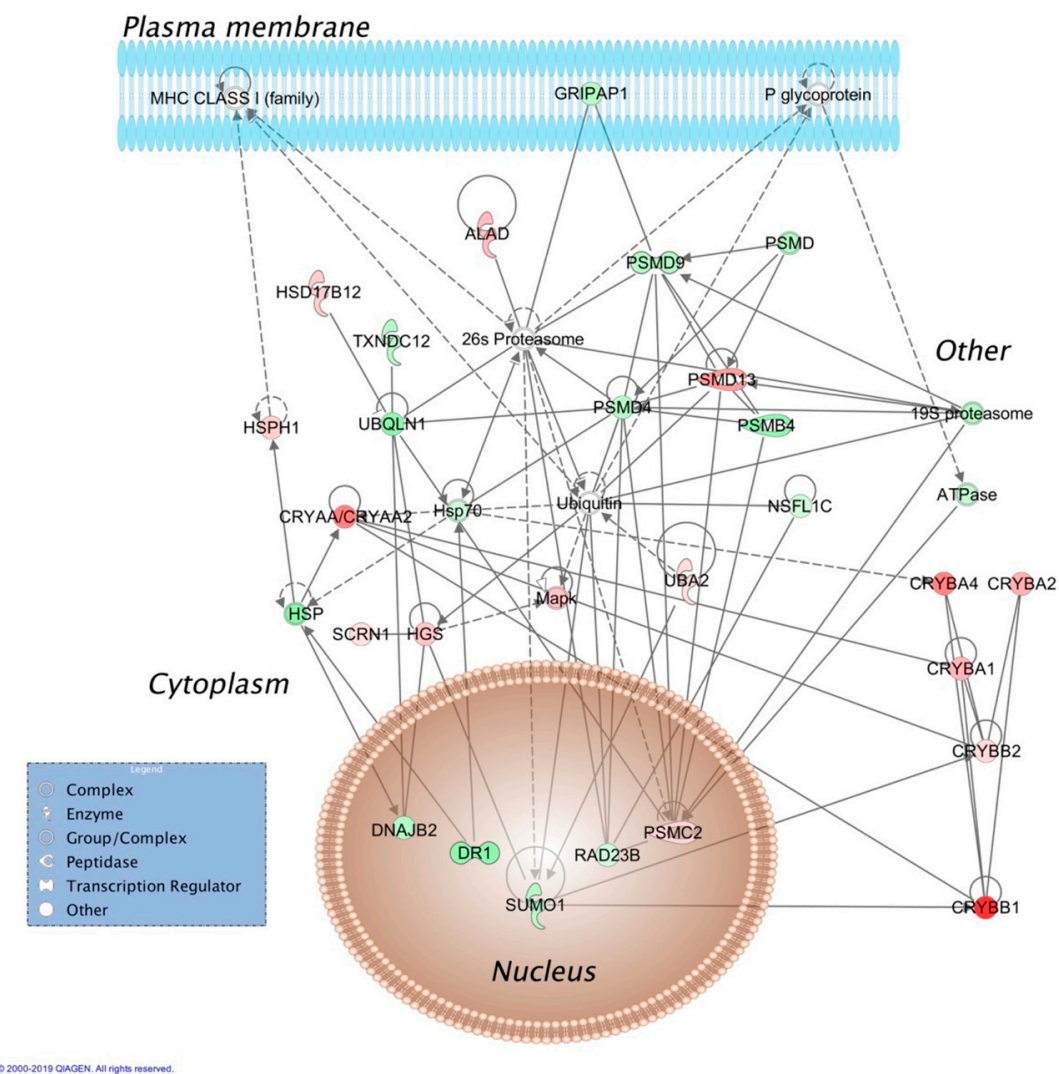

Figure 2. Molecular interaction network associated with development disorder, ophthalmic disease, organismal injury, and abnormalities assembled from retina proteins impacted by E2 given in eye drops to OVX rats. See explanation of shapes, colors and lines in the legend of Figure 1. Abbreviations: ALAD, aminolevulinate dehydratase; ATPase, adenosine triphosphatase; CRYAA/CRYAA2, $\alpha$-crystallin A/A2; CRYBA1, CRYBA2, CRYBA4, CRYBB1, and CRYBB2, $\beta$-crystallin A1, A2, A4, B1 and B2; DNAJ32, DnaJ heat shock protein family (Hsp40) member B2; DR1, down regulator of transcription 1; GRIPA1, glutamate receptor-interacting protein associated protein 1 ; HGS, hepatocyte growth factor-regulated tyrosine kinase substrate; HSD17B12, hydroxysteroid 17- $\beta$ dehydrogenase 12; HSP, heat shock protein; Hsp70, heat shock protein 70; HSPH1, heat shock protein family H (Hsp110) member 1; NSFL1C, $\mathrm{N}$-ethylmaleimide-sensitive factor L1 cofactor; PSMB4, proteasome subunit- $\beta$ 4; PSMC2, proteasome 26S subunit, non-ATPase 2; PSMD, proteasome 26S subunit, non-ATPase; PSMD4, PSMD9 and PSMD13, proteasome 26S subunit, non-ATPase 4, 9 and 13; RAD23B, nucleotide excision protein RAD23 homolog B; SCRN1, secernin 1; SUMO1, small ubiquitin-like modifier 1; TXNDC12, thioredoxin domain containing 12; UBA2, ubiquitin-like modifier activating enzyme 2; UBQLN1, ubiquilin 1.

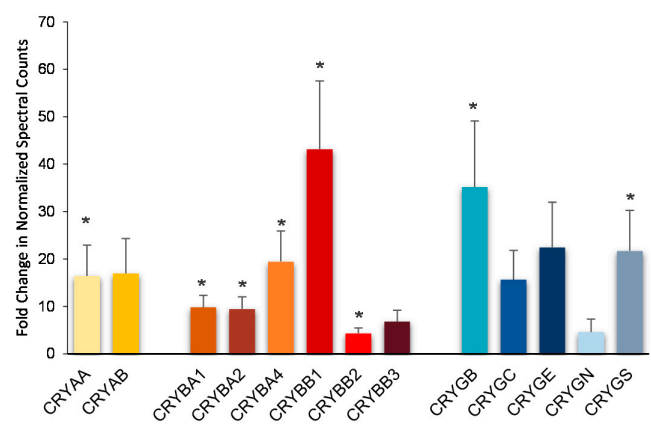

Figure 3. Upregulation of all crystallins was detected using normalized MS/MS spectral counts (SC) as quantitative measures in the retina of OVX rats after treatment with E2 given in eye drops. Fold changes are displayed as averages \pm standard error ( $n=5$ /group). Asterisks $\left(^{*}\right)$ indicate statistically significant differences of SC between treatment as control using unpaired $t$-tests. 
Table 1. (A) Molecular and cellular functions, as well as (B) physiological system development and function represented by significantly affected retina proteins identified by label-free quantitative proteomics in ovariectomized (OVX) Brown Norway rats that received topical $\mathrm{E}_{2}$ in eye drops.

\begin{tabular}{|c|c|c|}
\hline \multicolumn{3}{|c|}{ (A) } \\
\hline Represented Process & Number of Associated Molecules & $p$-Value of Overlap \\
\hline Cellular function and maintenance & 123 & $4.62 \cdot 10^{-3}-5.05 \cdot 10^{-13}$ \\
\hline Cellular assembly and organization & 117 & $4.79 \cdot 10^{-3}-5.05 \cdot 10^{-13}$ \\
\hline DNA replication, recombination and repair & 21 & $3.82 \cdot 10^{-3}-1.36 \cdot 10^{-11}$ \\
\hline Small-molecule biochemistry & 82 & $4.83 \cdot 10^{-3}-1.36 \cdot 10^{-11}$ \\
\hline Nucleic acid metabolism & 37 & $4.83 \cdot 10^{-3}-1.36 \cdot 10^{-11}$ \\
\hline \multicolumn{3}{|c|}{ (B) } \\
\hline Associated Physiology & Number of Linked Molecules & $p$-Value of Overlap \\
\hline Nervous system development and function & 92 & $4.62 \cdot 10^{-3}-5.56 \cdot 10^{-8}$ \\
\hline Tissue development & 74 & $4.24 \cdot 10^{-3}-3.40 \cdot 10^{-6}$ \\
\hline Organismal development & 60 & $4.24 \cdot 10^{-3}-3.40 \cdot 10^{-6}$ \\
\hline Organ development & 29 & $4.24 \cdot 10^{-3}-1.96 \cdot 10^{-4}$ \\
\hline Visual system development and function & 18 & $4.24 \cdot 10^{-3}-1.96 \cdot 10^{-4}$ \\
\hline
\end{tabular}

Table 2. Canonical pathways and targets associated with the network shown in Figure 1.

\begin{tabular}{cccc}
\hline Canonical Pathway & Targets & Z-Score & $p$-Value \\
\hline $\begin{array}{c}\text { Estrogen receptor } \\
\text { signaling }\end{array}$ & $\begin{array}{c}\text { estrogen receptor; G protein; Hdac; histone } \\
\text { deacetylase; N-cor; Pka; PLC; Ras; Ras homolog; Sfk }\end{array}$ & N/A & $6.03 \cdot 10^{-3}$ \\
\hline $\begin{array}{c}\text { ERK/MAPK signaling } \\
\text { estrogen receptor; G protein; Nfat; Pka; PLC; Ras; Ras } \\
\text { homolog; Sfk }\end{array}$ & 1.8 & $2.40 \cdot 10^{-2}$ \\
\hline
\end{tabular}

${ }^{1}$ Positive value: Activation of the canonical pathway; N/A: No prediction can be made.

Table 3. Canonical pathways and targets associated with the network shown in Figure 2.

\begin{tabular}{cccc}
\hline Canonical Pathway & Targets & Z-Score & $p$-Value \\
\hline $\begin{array}{c}\text { Protein ubiquitination } \\
\text { 19S proteasome; 26S proteasome; ATPase; }\end{array}$ & $\begin{array}{c}\text { CRYAA/CRYAA2; DNAJB2; Hsp70; HSP; HSPH1; } \\
\text { MHC CLASS I (family); PSMB4; PSMC2; PSMD4; } \\
\text { PSMD9; PSMD13; PSMD; Ubiquitin } \\
\text { endocytosis }\end{array}$ & N/A & $2.86 \cdot 10^{-6}$ \\
\hline $\begin{array}{c}\text { Clathrin-mediated } \\
\text { Synaptogenesis signaling }\end{array}$ & ATPase; HSP70; HSP; MAPK & N/A & $4.14 \cdot 10^{-9}$ \\
\hline${ }^{1}$ Positive value: Activation of the canonical pathway; N/A: No prediction can be made. &
\end{tabular}

\section{Discussion}

Previous physiological and pharmacological research have highlighted estrogen as a key regulator of retinal health $[17,18]$ and we have shown beneficial broad-spectrum neuroprotective effects of the topically applied $E_{2}$ in OVX rats that have no appreciable level of circulating hormone [20]. For the proteomics study presented here, we obtained samples relying on the previously employed treatment protocol. This will afford correlation of the results with those of apoptotic cell death in the ganglion cell layer and behavioral testing of visual performance published earlier [20]. Our results have enabled the assembly of protein networks that captured systems-level impacts of the hormone on the retina for the first time. It is expected that the wealth of information from this report will be valuable for neuroprotective ophthalmic therapy development relying on repurposing [6,8], polypharmacology [9], and target-focused new drug discovery [28], as well as for actual preventative medication aimed specifically at preserving the function of retinal ganglion cells (RGCs) from the postmenopausal impact 
of estrogen deficiency [29] alike. This expectation is justified especially in the context of emerging results from similar omics-driven profiling experiments on neurodegenerative diseases of the human eye [30] or animal models thereof [31-34].

We point out that our experimental approach focused on the identification of E2-regulated proteins was based on detecting changes in normalized spectral counts and not based on fold changes in absolute protein levels $[20,23]$. For proteins solubilized from a complex cellular proteome by an $8 \mathrm{M}$ aqueous urea solution, linear relationships of normalized spectral counts and protein levels have been shown comprehensively over a wide dynamic range [35]. Therefore (albeit with some degree of caution about some specific proteins as noted in the heading of Table S2), $\geq 2$-fold changes in normalized spectral counts [36] should have enabled reliable detections of statistically significant overall trends in up- and downregulation for the urea-solubilized retina proteins we report here.

A mechanistically meaningful target engagement by the $E_{2}$ delivered to the retina was revealed by the network shown in Figure 1, which implicated activation of signaling orchestrated by nuclear estrogen receptor (ER) as its top canonical pathway in association with cell morphology, cell to cell signaling, cellular growth, function and morphology as underlying biology. Messenger ribonucleic acid (mRNA) for ER expression has been shown in the eye [37], and the protein was detected in the retina [38,39]. Stimulation of extracellular signal-regulated kinase/mitogen-activated protein kinase (ERK/MAPK) signaling (listed in the inset table of the figure), a well-known mechanism critical for estrogen neuroprotection [40], was an additional pathway strongly linked to this network. Therefore, this previously shown ER-mediated neuroprotective effect of E2 in the retina and RGCs through ERKs [41,42] was supported by our data.

Another network shown in Figure 2, linked to development disorder, ophthalmic disease, organismal injury, and abnormalities by IPA ${ }^{\circledR}$, apparently captured the profound impact of $E_{2}$ on proteasome activity implicating the hormone's role in the clearance of damaged proteins [43]. Moreover, there were several crystallin isoforms of $\alpha$-crystallin (CRYAA/CRYAA2) and $\beta$-crystallin (CRYBA1, CRYBA2, CRYBA4, CRYBB1, and CRYBB2) strongly associated with this network. In other networks displayed in Figures S4 and S14 specifically linked to ophthalmic disease, $\gamma$-crystallin B (CRYGB) and $\gamma$-crystallin S (CRYGS) were also present. Crystallins represent a rather heterogeneous group of proteins with diverse functions in the eye $[44,45]$. In the retina, changes in their expression profile are considered an indication of a significant role of these proteins to maintain homeostasis [46]. Our mass spectrometry-based proteomics study has shown that all covered isoforms of crystallins are upregulated in the retina by $\mathrm{E}_{2}$ administered in eye drops, as summarized in Figure 3.

The $\alpha$-crystallins (CRYAA and CRYAB) interact with many proteins including other crystallins, cytoskeletal proteins, and proteins involved in inflammatory, signaling, angiogenic, and apoptotic pathways [47]. CRYAA and CRYAB function as molecular chaperones that prevent aberrant protein interactions $[48,49]$. Therefore, they protect key proteins and stabilize cells in the retina, as well as inhibit apoptosis-induced cell death [44,46]. Their overexpression promotes survival of RGCs injured by ocular hypertension and optic nerve crush [50,51]. On the other hand, a decrease of CRYAA has been associated with retinal dystrophy [52] and glaucomatous optic neuropathy [44]. However, intravitreal injection of CRYAB at the time of the intraocular pressure (IOP) increase rescued RGCs in a rat model of glaucoma [53]. The latter study also provided proteomic evidence that CRYAB injection upregulated all $(\alpha, \beta$ and $\gamma$ ) subclasses of crystallins in the retina, which induced the broad neuroprotective effects observed. Using the cauterization of episcleral veins to achieve chronic IOP elevation in rats as an experimental glaucoma model, a recent mass spectrometry-based proteomics experiment has established a potential correlation of age-related glaucomatous damage and the absence of all isoforms of the crystallin protein in the retina [54].

Compared to $\alpha$-crystallins, much less has been understood about the retinal function of $\beta$ and $\gamma$-cystallins $[43,44,55]$. Like CRYAA and CRYBB, $\beta$-crystallin genes are downregulated at both transcriptional and protein levels in rat retinas with ocular hypertension [56], and upregulation of $\beta$-crystallins has been linked to retina neuroprotection and axonal regeneration [55]. Moreover, CRYBB2 
upregulation during retinal regeneration in vitro and its localization in RGCs and their axons (including growth cones and filopodia) have also been reported [57]. Perhaps the most compelling evidence of the significance of CRYBB2 for retina neuroprotection has been that its intravitreal injection at the time of IOP elevation improves retinal ganglion cell survival in a rat model of glaucoma combined with mass spectrometry-based proteomics experiments [58]. Overall, the latter revealed CRYBB2's impact on calcium-dependent cell signaling pathways with profound effect on apoptosis and gene regulation, in which annexin $\mathrm{A} 5, \mathrm{Ca}^{2+}$-transporting ATPase 1, and various histone proteins supposedly play a major role. From our proteomics results, we could unequivocally confirm the connection of CRYBB2 upregulation in the rat retina by $\mathrm{E}_{2}$ with that of plasma membrane $\mathrm{Ca}^{2+}$-transporting ATPase 1 (AT2B1, Table S2), which may be associated with an estrogenic neuroprotective effect elicited by a non-genomic mechanism [16,59]. Beyond defense against glaucomatous neurodegeneration by $\beta$-cystallin(s), their protective role in type 2 epithelial-to-mesenchymal transition of retinal-pigment epithelial cells occurring in dry age-related macular degeneration has been shown recently [60]. However, all crystallins were found to be upregulated in a neonatal mouse model of oxygen-induced retinopathy [61-64], which indicated a developmental stage-dependent control of their expression. Nevertheless, our data summarized in Figure 3 support the observation about a highly correlated group of $\alpha_{-}, \beta-$, and $\gamma$-crystallin genes [65]. Therefore, it is not surprising that crystallin-based cell survival strategies have been proposed to protect and rescue RGCs from degeneration associated with glaucomatous and other optic neuropathies [50]. However, therapeutic protein delivery to the retina faces many obstacles [66-68] compared to small molecule therapy such as $E_{2}$ delivered topically [20], which would induce the desired changes in protein expression.

Many potential associations and pathways captured by Figures 1 and 2, as well as by the additional protein interaction networks of Figures S2-S17 have not been explored by research specifically addressing the retinal milieu. However, we anticipate that systems insights made possible by our results will guide future hypothesis-driven experiments focusing on the "estrogenic retina" [17,18], including potential therapeutic application of estrogens as topically delivered broad-spectrum retina neuroprotectants [20,69].

In conclusion, our mass spectrometry-based proteomics study has revealed a new, extended set of retina proteins significantly affected by the treatment of OVX Brown Norway rats with $\mathrm{E}_{2}$ administered in eye drops. Data provided evidence not only on multiple target engagements, but also afforded detailed bioinformatics analyses focusing on protein interaction networks and biological processes they represented. Strong associations of the impact with nervous system development and function, tissue development, organ development, as well as visual system development and function, argue for further consideration of estrogens for neuroprotective ophthalmic pharmacotherapy targeting the retina.

Supplementary Materials: The following are available online at http://www.mdpi.com/1999-4923/12/2/101/s1, Table S1: List of identified and validated proteins (Scaffold 4.9.0: $>95 \%$ and $>99 \%$ probability by Peptide Prophet and protein Prophet, respectively, with minimum of two unique peptides) in the retina, along with their gene ontology (GO) annotations, Figure S1: Biological processes and molecular processes associated with the identified rat retina proteins, and cellular localization of the identified rat retina proteins, Table S2: A list of E2-regulated retinal proteins in OVX rats, Figure S2: IPA ${ }^{\circledR}$ network linked to molecular transport, RNA posttranscriptional modification, RNA trafficking, Figure S3: IPA ${ }^{\circledR}$ network linked infectious disease, organismal injury and abnormalities, RNA posttranslational modification, Figure S4: IPA ${ }^{\circledR}$ network linked to cancer, infectious disease, organismal injury and abnormalities, Figure S5: IPA ${ }^{\circledR}$ network linked to cellular assembly and organization, cellular function and maintenance, connective tissue disorder, Figure S6: IPA ${ }^{\circledR}$ network linked to cell to cell signaling and interaction, cellular function and maintenance, nervous system development and function, Figure S7: IPA ${ }^{\circledR}$ network linked to carbohydrate metabolism, cellular compromise, cellular function and maintenance, Figure S8: IPA ${ }^{\circledR}$ network linked to cellular assembly and organization, energy production, nucleic acid metabolism, Figure S9: IPA ${ }^{\circledR}$ network linked to cell morphology, cellular assembly and organization, nervous system development and function, Figure S10: IPA ${ }^{\circledR}$ network linked to developmental disorder, hereditary disorder, metabolic function, Figure S11: IPA ${ }^{\circledR}$ network linked to gene expression, RNA damage and repair, RNA post translational modification and repair, Figure S12: IPA ${ }^{\circledR}$ network linked to nucleic acid metabolism, protein synthesis, small-molecule biochemistry, 
Figure S13: IPA ${ }^{\circledR}$ network linked to cellular assembly and organization, cellular function and maintenance, and tissue development, Figure S14: IPA ${ }^{\circledR}$ network linked to cell morphology, cellular function and maintenance, and cellular compromise, Figure S15: IPA ${ }^{\circledR}$ network linked to cancer, cellular growth and proliferation, organismal injury and compromise, Figure S16: IPA ${ }^{\circledR}$ network linked to amino acid metabolism, cellular assembly and organization, small-molecule biochemistry, Figure S17: IPA ${ }^{\circledR}$ network linked to cell death and survival, cellular development, cellular growth and proliferation, Figure S18: Overlapping IPA ${ }^{\circledR}$ networks.

Author Contributions: Conceptualization, L.P. and K.P.-T.; methodology, L.P., K.Z., K.P.-T., and V.N.; investigation, K.Z., V.N., and K.P. -T.; resources, L.P. and K.P.-T.; writing-original draft preparation, L.P.; writing-review and editing, K.Z. and K.P.-T.; visualization, L.P. and K.Z.; supervision, L.P. and K.P.-T.; project administration, L.P. and K.P.-T.; funding acquisition K.P.-T. and L.P. All authors have read and agreed to the published version of the manuscript.

Funding: This work was supported by the National Eye Institute and the Office of Research on Women's Health (National Institutes of Health, Bethesda, MD, USA, grant number EY027005 to K.P.-T.) and by the Robert A. Welch Foundation (endowment BK-0031 to L.P.).

Acknowledgments: The authors appreciate the participation of Fatima Rahlouni in method development, preliminary experiments, and technical support.

Conflicts of Interest: L.P. and K.P.-T. are inventors in the patents covering the use of a bioprecursor prodrugs for estrogens as ophthalmic agents and are co-founders of AgyPharma LLC with equity in the company that licensed the patents. K.Z. and V.N. declare no conflict of interest.

\section{References}

1. Gower, N.J.D.; Barry, R.J.; Edmunds, M.R.; Titcomb, L.C.; Denniston, A.K. Drug discovery in ophthalmology: past success, present challenges, and future opportunities. BMC Ophthalmol. 2016, 16, 11. [CrossRef]

2. Cursiefen, C.; Cordeiro, F.; Cunha-Vaz, J.; Wheeler-Schilling, T.; Scholl, H.P.N. Unmet needs in ophthalmology: A European Vision Institute-consensus roadmap 2019-2025. Ophthalmic Res. 2019, 62, 123-133. [CrossRef]

3. Schmidt, K.G.; Bergert, H.; Funk, R.H. Neurodegenerative diseases of the retina and potential for protection and recovery. Curr. Neuropharmacol. 2008, 6, 164-178. [CrossRef]

4. Katz, M.; Hubbard, W.A.; Getson, A.J.; Gould, A.L. Intraocular pressure decrease in normal volunteers following timolol ophthalmic solution. Invest. Ophthalmol. 1976, 15, 489-492.

5. McAnally, D.; Siddiquee, K.; Gomaa, A.; Szabo, A.; Vasile, S.; Maloney, P.R.; Divlianska, D.B.; Peddibhotla, S.; Morfa, C.J.; Hershberger, P.; et al. Repurposing antimalarial aminoquinolines and related compounds for treatment of retinal neovascularization. PLoS ONE 2018, 13, e0202436. [CrossRef]

6. McClure, D.A. Effect of a pro-drug of epinephrine (dipivalyl epinephrine) in glaucoma-general pharmacology, toxicology, and clinical experience. ACS Sym. Ser. 1975, 14, 224-235.

7. Bodor, N.; Prokai, L. Site- and stereospecific drug delivery by sequential enzymatic bioactivation. Pharm. Res. 1990, 7, 723-725. [CrossRef]

8. Prokai, L.; Prokai, K.; Simpkins, J.; Agarwal, N. Prodrugs for Use as Ophthalmic Agents. U.S. Patent 7,186,707, 6 March 2007.

9. Chen, Y.; Palczewski, K. Systems pharmacology links GPCRs with retinal degenerative disorders. Annu. Rev. Pharmacol. Toxicol. 2016, 56, 273-298. [CrossRef]

10. Sunshine, W.L. The promise of topicals for retinal disease. Retinal Physician 2017, 14, 51-52.

11. Adams, C.M.; Stacy, R.; Rangaswamy, N.; Bigelow, C.; Grosskreutz, C.L.; Prasanna, G. Glaucoma-next generation therapeutics: impossible to possible. Pharm. Res. 2019, 36, 25. [CrossRef]

12. Fang, J.; Jiang, F.; Li, J.; Zhu, Y. Rationale for the use of multifunctional drugs as neuroprotective agents for glaucoma. Neural. Regen. Res. 2011, 6, 313-318.

13. Moggs, J.G.; Orphanides, G. Estrogen receptors: orchestrators of pleiotropic cellular responses. EMBO Rep. 2001, 21, 775-781. [CrossRef]

14. Hewitt, S.C.; Harrell, J.C.; Korach, K.S. Lessons in estrogen biology from knockout and transgenic animals. Annu. Rev. Physiol. 2005, 67, 285-308. [CrossRef]

15. Behl, C. Oestrogen as a neuroprotective hormone. Nat. Rev. Neurosci. 2002, 3, 433-442. [CrossRef]

16. Prokai-Tatrai, K.; Prokai, L. Sex Hormones in Neurodegenerative Processes and Diseases; Drevensek, G., Ed.; IntechOpen: Rijeka, Croatia, 2018; pp. 21-39. 
17. Cascio, C.; Deidda, I.; Russo, D.; Guarneri, P. The estrogenic retina: The potential contribution to healthy aging and age-related neurodegenerative diseases of the retina. Steroids 2015, 103, 31-41. [CrossRef]

18. Nuzzi, R.; Scalabrin, S.; Becco, A.; Panzica, G. Gonadal hormones and retinal disorders: A review. Front. Endocrinol. 2018, 9, 66. [CrossRef]

19. Chen, X.; Liu, Y.; Zhang, Y.; Kam, W.R.; Pasquale, L.R.; Sullivan, D.A. Impact of aromatase absence on murine intraocular pressure and retinal ganglion cells. Sci. Rep. 2018, 8, 3280. [CrossRef]

20. Prokai-Tatrai, K.; Xin, H.; Nguyen, V.; Szarka, S.; Blazics, B.; Prokai, L.; Koulen, P. 17ß-Estradiol eye drops protect the retinal ganglion cell layer and preserve visual function in an in vivo model of glaucoma. Mol. Pharmaceut. 2013, 10, 3253-3261. [CrossRef]

21. Rakic, J.M.; Lambert, V.; Deprez, M.; Foidart, J.M.; Noel, A.; Munaut, C. Estrogens reduce the expression of YKL-40 in the retina: Implications for eye and joint diseases. Invest. Ophthalmol. Vis. Sci. 2003, 44, 1740-1746. [CrossRef]

22. D'Anna, C.; Cascio, C.; Cigna, D.; Galizzi, G.; Deidda, I.; Bianchi, L.; Russo, D.; Passantino, R.; Bini, L.; Guarneri, P. A retinal proteomics-based study identifies alpha A-crystallin as a sex steroid-regulated protein. Proteomics 2011, 11, 986-990. [CrossRef]

23. Prokai, L.; Stevens, S.M., Jr.; Rauniyar, N.; Nguyen, V. Rapid label-free identification of estrogen-induced differential protein expression in vivo from mouse brain and uterine tissue. J. Proteome Res. 2009, 8, 3862-3871. [CrossRef] [PubMed]

24. Keller, A.; Nesvizhskii, A.I.; Kolker, E.; Aebersold, R. Empirical statistical model to estimate the accuracy of peptide identifications made by MS/MS and database search. Anal. Chem. 2002, 74, 5383-5392. [CrossRef] [PubMed]

25. Nesvizhskii, A.I.; Keller, A.; Kolker, E.; Aebersold, R. A statistical model for identifying proteins by tandem mass spectrometry. Anal. Chem. 2003, 75, 4646-4658. [CrossRef] [PubMed]

26. Vizcaíno, J.A.; Deutsch, E.W.; Wang, R.; Csordas, A.; Reisinger, F.; Ríos, D.; Dianes, J.A.; Sun, Z.; Farrah, T.; Bandeira, N.; et al. ProteomeXchange provides globally coordinated proteomics data submission and dissemination. Nat. Biotechnol. 2014, 30, 223-226. [CrossRef]

27. Tutorials: Understanding the P-Value of Overlap Statistic in IPA. Available online: https://tv. qiagenbioinformatics.com/video/19605716/understanding-the-p-value-of (accessed on 11 January 2020).

28. Zhang, K.; Zhang, L.; Weinreb, R.N. Ophthalmic drug discovery: novel targets and mechanisms for retinal diseases and glaucoma. Nat. Rev. Drug. Discov. 2012, 11, 541-559. [CrossRef]

29. Deschenes, M.C.; Descovich, D.; Moreau, M.; Granger, L.; Kuchel, G.A.; Mikkola, T.S.; Fick, G.H.; Chemtob, S.; Vaucher, E.; Lesk, M.R. Postmenopausal hormone therapy increases retinal blood flow and protects the retinal nerve fiber layer. Invest. Ophthalmol. Vis. Sci. 2010, 51, 2587-2600. [CrossRef]

30. Funke, S.; Perumal, N.; Beck, S.; Gabel-Scheurich, S.; Schmelter, C.; Teister, J.; Gerbig, C.; Gramlich, O.W.; Pfeiffer, N.; Grus, F.H. Glaucoma related proteomic alterations in human retina samples. Sci. Rep. 2016, 6, 29759. [CrossRef]

31. Campello, L.; Esteve-Rudd, J.; Bru-Martinez, R.; Herrero, M.T.; Fernandez-Villalba, E.; Cuenca, N.; Martin-Nieto, J. Alterations in energy metabolism, neuroprotection and visual signal transduction in the retina of parkinsonian, MPTP-treated monkeys. PLoS ONE 2013, 8, UNSP-e74439. [CrossRef]

32. Anders, F.; Teister, J.; Funke, S.; Pfeiffer, N.; Grus, F.; Solon, T.; Prokosch, V. Proteomic profiling reveals crucial retinal protein alterations in the early phase of an experimental glaucoma model. Graefes Arch. Clin. Exp. Ophthalmol. 2017, 255, 1395-1407. [CrossRef]

33. Ruzafa, N.; Pereiro, X.; Lepper, M.F.; Hauck, S.M.; Vecino, E. A proteomics approach to identify candidate proteins secreted by Muller glia that protect ganglion cells in the retina. Proteomics 2018, 18, 1700321. [CrossRef]

34. Saddala, M.S.; Lennikov, A.; Grab, D.J.; Liu, G.S.; Tang, S.B.; Huang, H. Proteomics reveals ablation of PIGF increases antioxidant and neuroprotective proteins in the diabetic mouse retina. Sci. Rep. 2018, 8, 16728. [CrossRef]

35. Liu, H.; Sadygov, R.G.; Yates, J.R., III. A model for random sampling and estimation of relative protein abundance in shotgun proteomics. Anal. Chem. 2004, 76, 4193-4201. [CrossRef]

36. Zhang, B.; VerBerkmoes, N.C.; Langston, M.A.; Uberbacher, E.; Hettich, R.L.; Samatova, N.F. Detecting differential and correlated protein expression in label-free shotgun proteomics. J. Proteome Res. 2006, 5, 2909-2918. [CrossRef] 
37. Wickham, L.A.; Gao, J.P.; Toda, I.; Rocha, E.M.; Ono, M.; Sullivan, D.A. Identification of androgen, estrogen and progesterone receptor mRNAs in the eye. Acta Ophthalmol. Scand. 2000, 78, 146-153. [CrossRef]

38. Kobayashi, K.; Kobayashi, H.; Ueda, M.; Honda, Y. Estrogen receptor expression in bovine and rat retinas. Invest. Ophthalmol. Vis. Sci. 1998, 39, 2105-2110.

39. Munaut, C.; Lambert, V.; Noel, A.; Frankenne, F.; Deprez, M.; Foidart, J.M.; Rakic, J.M. Presence of oestrogen receptor type beta in human retina. Br. J. Ophthalmol. 2001, 85, 877-885. [CrossRef]

40. Lebesgue, D.; Chevaleyre, V.; Zukin, R.S.; Etgen, A.M. Estradiol rescues neurons from global ischemia-induced cell death: Multiple cellular pathways of neuroprotection. Steroids 2009, 74, 555-561. [CrossRef]

41. Hayashi, Y.; Kitaoka, Y.; Munemasa, Y.; Ohtani-Kaneko, R.; Kikusui, T.; Uematsu, A.; Takeda, H.; Hirata, K.; Mori, Y.; Ueno, S. Neuroprotective effect of 17 beta-estradiol against N-methyl-D-aspartate-induced retinal neurotoxicity via p-ERK induction. J. Neurosci. Res. 2007, 85, 386-394. [CrossRef]

42. Nakazawa, T.; Takahashi, H.; Shimura, M. Estrogen has a neuroprotective effect on axotomized RGCs through ERK signal transduction pathway. Brain Res. 2006, 1093, 141-149. [CrossRef]

43. Reed, J.L.; Dimayuga, F.O.; Davies, L.M.; Keller, J.N.; Bruce-Keller, A.J. Estrogen increases proteasome activity in murine microglial cells. Neurosci. Lett. 2004, 367, 60-65. [CrossRef]

44. Andley, U.P. Crystallins in the eye: Function and pathology. Prog. Retin. Eye Res. 2007, 26, 78-98. [CrossRef] [PubMed]

45. Slingsby, C.; Wistow, G.J. Functions of crystallins in and out of lens: Roles in elongated and post-mitotic cells. Prog. Biophys. Mol. Biol. 2014, 115, 52-67. [CrossRef] [PubMed]

46. Xi, J.; Farjo, R.; Yoshida, S.; Kern, T.S.; Swaroop, A.; Andley, U.P. A comprehensive analysis of the expression of crystallins in mouse retina. Mol. Vis. 2003, 9, 410-419. [PubMed]

47. Kannan, R.; Sreekumar, P.G.; Hinton, D.R. Novel roles for alpha-crystallins in retinal function and disease. Prog. Retin. Eye Res. 2012, 31, 576-604. [CrossRef] [PubMed]

48. Horwitz, J. Alpha-crystallin can function as a molecular chaperone. Proc. Natl. Acad. Sci. USA 1992, 89, 10449-10453. [CrossRef]

49. Horwitz, J. Alpha-crystallin. Exp. Eye Res. 2003, 76, 145-153. [CrossRef]

50. Piri, N.; Kwong, J.M.K.; Caprioli, J. Crystallins in retinal ganglion cell survival and regeneration. Mol. Neurobiol. 2013, 48, 819-828. [CrossRef]

51. Piri, N.; Kwong, J.M.K.; Gu, L.; Caprioli, J. Heat shock proteins in the retina: Focus on HSP70 and alpha crystallins in ganglion cell survival. Prog. Retin. Eye Res. 2016, 52, 22-46. [CrossRef]

52. Maeda, A.; Ohguro, H.; Maeda, T.; Nakagawa, T.; Kuroki, Y. Low expression of alphaA-crystallins and rhodopsin kinase of photoreceptors in retinal dystrophy rat. Invest. Ophthalmol. Vis. Sci. 1999, 40, 2788-2794.

53. Anders, F.; Liu, A.W.; Mann, C.; Teister, J.; Lauzi, J.; Thanos, S.; Grus, F.H.; Pfeiffer, N.; Prokosch, V. The small heat shock protein alpha-crystallin B shows neuroprotective properties in a glaucoma animal model. Int. J. Mol. Sci. 2017, 18, 2418. [CrossRef]

54. Anders, F.; Mann, C.; Liu, A.W.; Teister, J.; Funke, S.; Thanos, S.; Grus, F.; Pfeiffer, N.; Prokosch, V. Correlation of crystallin expression and RGC susceptibility in experimental glaucoma rats of different ages. Curr. Eye Res. 2018, 43, 1267-1273. [CrossRef] [PubMed]

55. Thanos, S.; Bohm, M.R.R.; Horste, M.M.Z.; Prokosch-Willing, V.; Hennig, M.; Bauer, D.; Heiligenhaus, A. Role of crystallins in ocular neuroprotection and axonal regeneration. Prog. Retin. Eye Res. 2014, 42, 145-161. [CrossRef] [PubMed]

56. Piri, N.; Song, M.; Kwong, J.M.K.; Caprioli, J. Modulation of alpha and beta crystallin expression in rat retinas with ocular hypertension-induced ganglion cell degeneration. Brain Res. 2007, 1141, 1-9. [CrossRef] [PubMed]

57. Liedtke, T.; Schwamborn, J.C.; Schroer, U.; Thanos, S. Elongation of axons during regeneration involves retinal crystallin beta b2 (crybb2). Mol. Cell. Proteom. 2007, 6, 895e907. [CrossRef] [PubMed]

58. Anders, F.; Teister, J.; Liu, A.; Funke, S.; Grus, F.H.; Thanos, S.; von Pein, H.D.; Pfeiffer, N.; Prokosch, V. Intravitreal injection of $\beta$-crystallin $\mathrm{B} 2$ improves retinal ganglion cell survival in an experimental animal model of glaucoma. PLoS ONE 2017, 12, e0175451. [CrossRef] [PubMed]

59. Prokai, L.; Simpkins, J.W. Structure-non-genomic neuroprotection relationship of estrogens and estrogen-derived compounds. Pharmacol. Therapeut. 2007, 114, 1-12. [CrossRef] 
60. Ghosh, S.; Shang, P.; Terasaki, H.; Stepicheva, N.; Hose, S.; Yazdankhah, M.; Weiss, J.; Sakamoto, T.; Bhutto, I.A.; Xia, S.L.; et al. A role for beta A3/A1-crystallin in type 2 EMT of RPE cells occurring in dry age-related macular degeneration. Invest. Ophthalmol. Vis. Sci. 2018, 59, 104-113. [CrossRef]

61. Zhou, L.; Liu, X.; Koh, S.K.; Li, X.; Beuerman, R.W. Quantitative proteomic analysis of retina in oxygen-induced retinopathy mice using iTRAQ with 2D nanoLC-nanoESI-MS/MS. JIOMICS 2011, 1, 226-235.

62. Kim, S.J.; Jin, J.; Kim, Y.J.; Kim, Y.; Yu, H.G. Retinal proteome analysis in a mouse model of oxygen-induced retinopathy. J. Proteome Res. 2012, 11, 5186-5203. [CrossRef]

63. Tu, C.J.; Beharry, K.D.; Shen, X.M.; Li, J.; Wang, L.S.; Aranda, J.V.; Qu, J. Proteomic profiling of the retinas in a neonatal rat model of oxygen-induced retinopathy with a reproducible ion-current-based MS1 approach. J. Proteome Res. 2015, 14, 2109-2120. [CrossRef]

64. Vähätupa, M.; Nättinen, J.; Jylhä, A.; Aapola, U.; Kataja, M.; Kööbi, P.; Järvinen, T.A.H.; Uusitalo, H.; Uusitalo-Järvinen, H. SWATH-MS proteomic analysis of oxygen-induced retinopathy reveals novel potential therapeutic targets. Invest. Ophthalmol. Vis. Sci. 2018, 59, 3294-3306.

65. Templeton, J.P.; Wang, X.D.; Freeman, N.E.; Ma, Z.W.; Lu, A.; Hejtmancik, F.; Geisert, E.E. A crystalline gene network in the mouse retina. Exp. Eye Res. 2013, 116, 129-140. [CrossRef] [PubMed]

66. Vyas, S.P.; Paliwal, R.; Paliwal, S.R. Ocular delivery of peptides and proteins. In Peptide and Protein Delivery, Van Der Walle, C., Ed.; Elsevier: Amsterdam, The Netherlands, 2011; pp. 87-103.

67. Joseph, M.; Trinh, H.M.; Cholkar, K.; Pal, D.; Mitra, A.K. Recent perspectives on the delivery of biologics to back of the eye. Expert Opin. Drug Deliv. 2017, 14, 631-645. [CrossRef] [PubMed]

68. Mandal, A.; Pal, D.; Agrahari, V.; Trinh, H.M.; Joseph, M.; Mitra, A.K. Ocular delivery of proteins and peptides: Challenges and novel formulation approaches. Adv. Drug Deliv. Rev. 2018, 126, 67-95. [CrossRef] [PubMed]

69. Prokai-Tatrai, K.; Prokai, L. Prodrugs for central nervous system-selective estrogen therapy. Molecules 2019, 24, 4197. [CrossRef]

(C) 2020 by the authors. Licensee MDPI, Basel, Switzerland. This article is an open access article distributed under the terms and conditions of the Creative Commons Attribution (CC BY) license (http://creativecommons.org/licenses/by/4.0/). 